\title{
Time and seasonal patterns of activity of phyllostomid in fragments of a stational semidecidual forest from the Upper Paraná River, Southern Brazil
}

\author{
Ortêncio Filho, H. ${ }^{a, b *}$, Reis, NR. ${ }^{c}$ and Minte-Vera, $C V^{d}$ \\ a Departamento de Biologia, Programa de Pós-graduação em Ecologia de Ambientes Aquáticos Continentais, \\ Universidade Estadual de Maringá - UEM, Av. Colombo, 5.790, Jd. Universitário, CEP 87020-900, Maringá, Paraná, Brazil

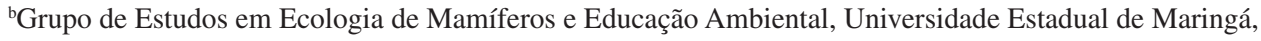 \\ Av. Reitor Zeferino Vaz, s/n, CEP 87360-000, Goioerê, PR, Brazil \\ 'Universidade Estadual de Londrina - UEL, CP 6001, CEP 86051-990, Londrina, PR, Brazil

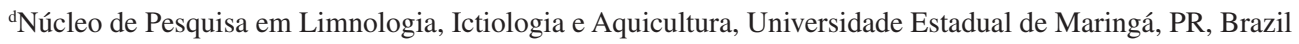 \\ *e-mail: henfilho@uem.br
}

Received May 28, 2009 - Accepted August 21, 2009 - Distributed November 30, 2010

(With 5 figures)

\begin{abstract}
Bats may exhibit different patterns of activity, considering aspects concerning niche dynamics as well as the establishment and permanence of the communities in the ecosystems. In this way, the present study analyzed the time and seasonal patterns of activity in different species of frequent phyllostomid bats in remnants of the stational semidecidual forest from the Upper Paraná River, Southern Brazil. Captures were performed between January and December, 2006, using 32 mist nets set above the soil along the nocturnal period during the four seasons of the year. The daily and seasonal patterns of activity of each species was modeled using generalized linear models with Poisson error. The best model was selected using Akaike's Information Criterion (AICc). Artibeus planirostris (Spix, 1823) did not exhibit a conspicuous time pattern, whereas A. lituratus (Olfers, 1818) was more frequent after the sixth hour and A. fimbriatus Gray, 1838 had an activity increase along the night. Platyrrhinus lineatus (E. Geoffroy, 1810) was registered during all sampling hours. Carollia perspicillata (Linnaeus, 1758) and Sturnira lilium (E. Geoffroy, 1810) were the most active during the first four hours. Concerning seasonal pattern, the highest activity of these species was verified during the summer. These data contribute to the information about the ecology of bats in the region, highlighting the high adaptive potential of the species studied in relation to the use of space throughout the night and in to variations in environmental conditions.
\end{abstract}

Keywords: phyllostomid bats, time activity, seasonal activity, stational semidecidual forest.

\section{Padrões de atividade horária e sazonal de morcegos filostomídeos em fragmentos de floresta estacional semidecidual do alto rio Paraná, sul do Brasil}

\begin{abstract}
Resumo
Os morcegos podem exibir diferentes padrões de atividade, considerando-se aspectos relacionados à dinâmica de nicho e ao estabelecimento e permanência das comunidades nos ecossistemas. Assim, o presente estudo teve por objetivo investigar o padrão de atividade horária e sazonal em diferentes espécies de morcegos, frequentes em remanescentes de floresta estacional semidecidual do alto rio Paraná, sul do Brasil. As coletas foram realizadas entre janeiro e dezembro de 2006, com o auxílio de 32 redes armadas acima do solo, ao longo de todo o período noturno e nas quatro estações do ano. A análise dos dados contemplou o uso de modelos lineares generalizados Akaike's Information Criterion (AICc) e distribuição de Poisson. Artibeus planirostris (Spix, 1823) não exibiu um padrão horário conspícuo, enquanto $A$. lituratus (Olfers, 1818) foi mais frequente após a sexta hora e A. fimbriatus Gray, 1838 teve aumento da atividade ao longo da noite. Platyrrhinus lineatus (E. Geoffroy, 1810) foi registrado durante todas as horas de amostragem. Carollia perspicillata (Linnaeus, 1758) e Sturnira lilium (E. Geoffroy, 1810) foram mais ativos nas quatro primeiras horas. Em relação ao padrão sazonal, constatou-se maior atividade dessas espécies durante o verão. Esses dados contribuem com as informações acerca da ecologia dos morcegos na região e evidenciam o alto potencial adaptativo das espécies estudadas à variação de tempo e condições ambientais.
\end{abstract}

Palavras-chave: morcegos filostomídeos, atividade horária, atividade sazonal, floresta estacional semidecidual. 


\section{Introduction}

In Brazil, about $25 \%$ of mammal species belongs to Chiroptera Order (Reis et al., 2006), distributed in nine families, 64 genera and 167 species; this group is represented throughout every Brazilian territory, ocurring in Amazonian, Cerrado, Atlantic forest, Pantanal and Caatinga (Reis et al., 2007).

The chiropterans are easily found in forests and present wide diversity regarding ecological aspects, as selection of diet, shelter and habitat and they have been considered as important environmental indicators of altered areas (Fenton et al., 1992; Medellín et al., 2000; Peters et al., 2006). Among the functions carried out in ecosystems by interacting with other organisms, there is important role in pollination (Gardner, 1977), seed dispersal (Van Der Pjil, 1957) and in the natural control of insects (Goodwin and Greenhall, 1961).

The habitat fragmentation process is a crucial aspect to be considered when preserving the wild life, since the reduction of the environments in smaller areas results in a limitation of essential resources to the species maintenance, as food, reproductive partners and shelter (Pires et al., 2006). Additionally, the alteration in the microclimate of these areas originated by the anthropogenic activity has caused changes in temperature, luminosity and humidity (Odum and Barrett, 2007), conditions that may influence the bats activities (Thies et al., 2006). Moreover, according to Agosta et al. (2005), intrinsic characteristics of the species may result in distinct activity patterns.

The knowledge about the time and season with highest activity of bats is critical to define actions to preserve this group (Goiti et al., 2006), considering the importance of these animals in the maintenance of several ecological processes, as pollination, seed dispersal (Van der Pjil, 1957) and natural control of insects (Goodwin and Greenhall, 1961).

Many studies investigating the time activity (Reis, 1984; Muller and Reis, 1992; Fogaça, 2003; Zanon and Reis, 2007; Ortêncio Filho and Reis, 2008) only focus the first hours after the nightfall, according to Brown (1968) and Laval (1970), and emphasize that the first hours of the night comprise the period with the highest bats activity in Neotropical region. Sipinski and Reis (1995) observed that researches performed during three sampling hours after the nightfall were enough for basic studies of bats ecology.

Others studies demonstrated variations in the activity time of chiropterans, focussing on the possibility of more than one peak throughout nocturnal period (Morrison, 1978; Pedro, 1992; Pedro and Taddei, 2002; Bernard, 2002), which highlight the need to sample such pattern throughout entire night period.

Several issues related to the bats ecology may be understood from information about time and seasonal patterns of activity, as environment exploitation, diet and reproduction, which allow the knowledge about the niche dynamics and the establishment and permanence of communities within the ecosystems (Pianka, 1969; Schoener, 1974), besides contributing for the distinction of ecologically similar species (Marinho-Filho and Sazima, 1989; Muller and Reis, 1992; Pedro, 1992; Pedro and Taddei, 1997, 2002).

In this way, the present study assumed that there is a variation in the time and seasonal pattern of activity of frugivorous phyllostomid, with highest activity during the first hours of the night in the summer, at remnants from the stational semidecidual forest of the Upper Paraná River, Brazil.

\section{Material and Methods}

The study was accomplished in the area that encompasses the upper stretch of the Paraná River. The climate is classified as humid subtropical mesothermic (Cfa), with mean temperatures, in winter, lower than $18^{\circ} \mathrm{C}$, with uncommon frosts; and during the summer, higher than $22{ }^{\circ} \mathrm{C}$ and tendency of rainfall concentrations (Agostinho and Zalewski, 1996). The annual precipitation ranges from $1,400 \mathrm{~mm}$ to $1,500 \mathrm{~mm}$ (IAPAR, 1994).

The area is formed by stational semidecidual forest (Campos and Souza, 1997). The identified families and that best represent the species richness are: Leguminosae (12.6\%), Poaceae (7.1\%), Euphorbiaceae (5.4\%), Rubiaceae (4.9\%), Cyperaceae (4.1\%), Myrtaceae (5.4\%) and Asteraceae (3.1\%) (Souza and Kita, 2002).

Samplings were carried out in four fragments: 1) Field station $\left(22^{\circ} 45^{\prime} \mathrm{S}\right.$ and $\left.53^{\circ} 15^{\prime} \mathrm{W}\right)$ : degraded forest remnant in recovering process of about $1.7 \mathrm{ha}$, located in the neighborhood of the Caracu stream, a small tributary in the left bank of the Upper Paraná River, situated at Porto Rico County, Paraná State, in the surroundings of the Field Station of the Universidade Estadual de Maringá (Souza et al., 2005); 2) Mutum Island (22\%48'18'S and 5313'26”W): located between the Taquaruçu (Mato Grosso do Sul State) and Porto Rico (Paraná State) municipal districts. The total area with approximately 1,012 ha is characterized by changes in the vegetation, produced by unruly processes of deforestation and soil use. The island is formed by several fragments and the sampling stations comprised about 1.5 ha (Correa, 1998); 3) Araldo Forest (22 47'37'S and 53 $19^{\prime}$ '03'W): this forest remnant with about 20.0 ha is located in the left bank of the Upper Paraná River and present a marginal strip subjected to flooding during the seasonal floods (Souza and Monteiro, 2005); 4) Unida Farm ( $22^{\circ} 41^{\prime} 01^{\prime \prime} \mathrm{S}$ and $\left.53^{\circ} 17^{\prime} 34^{\prime \prime} \mathrm{W}\right)$ : this forest remnant is in the right bank of the Baía River, one of the main affluent of the right bank of the Upper Paraná River, and is divided in a very disturbed area and another less disturbed one, and is isolated by a matrix for the cultivation of exotic fruit species, pasture and natural regeneration, with 1.22 ha (Souza, 2004) (Figure 1).

To capture the bats, 32 mist nets were employed, with $8.0 \mathrm{~m} \times 2.5 \mathrm{~m}$, resulting in $640 \mathrm{~m}^{2} \mathrm{~h}$ per hour and totaling a capture effort of $87,040 \mathrm{~m}^{2} \mathrm{~h}$ (Straube and Bianconi, 2002), the nets were set between 0.5 and $3.0 \mathrm{~m}$ from the soil, favoring the capture of frugivorous phyllostomids, that due to the higher food availability, frequent the stratum 


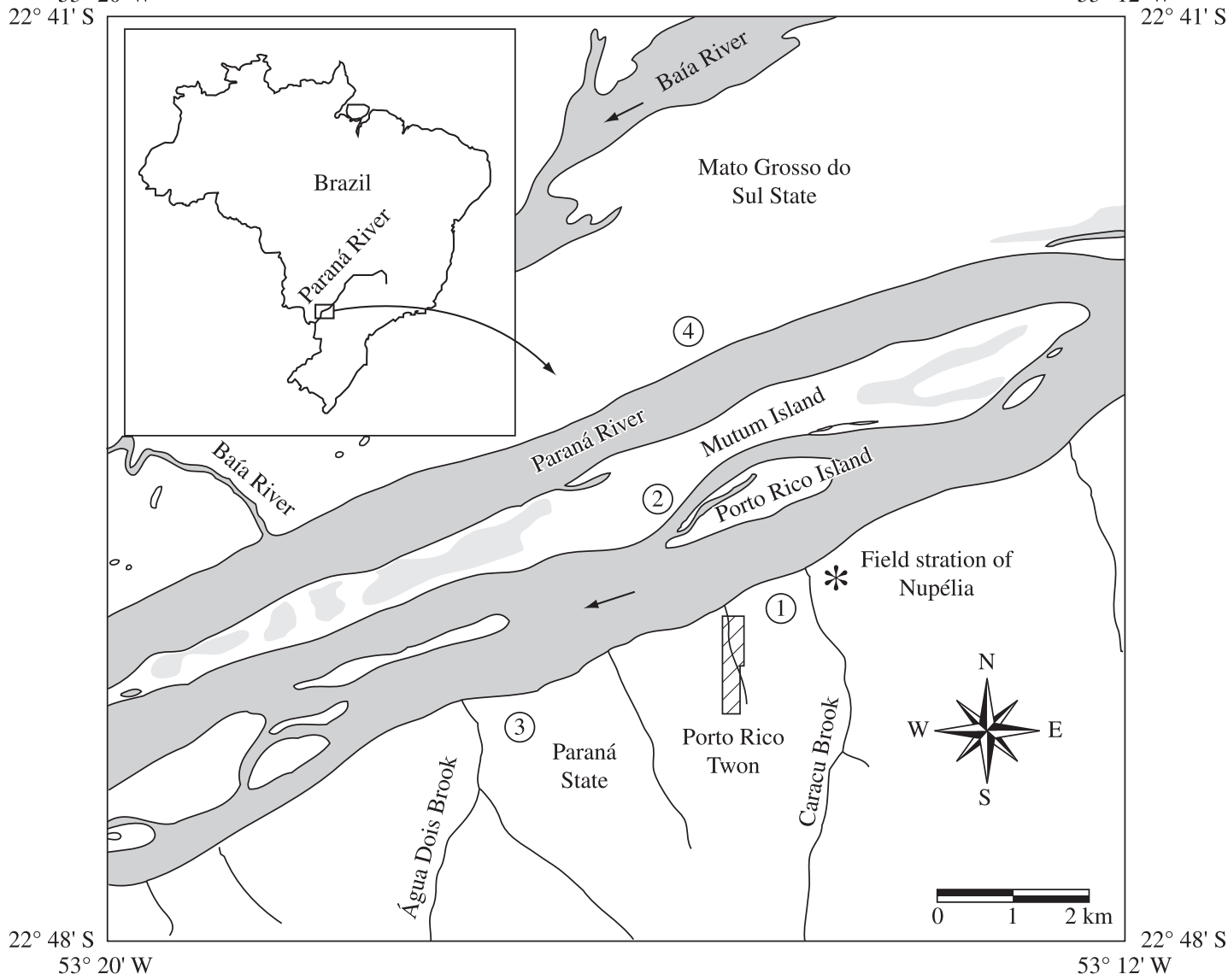

Figure 1. Area of captures with the respective selected sampling sites in the Paraná River floodplain: 1) Field Station, 2) Mutum Island, 3) Araldo Forest and 4) Unida Farm.

corresponding to the sub-forest (Pedro, 1998). The capture methods were based on Greenhall and Paradiso (1968), with the nets set in the places with high preference of bats in their displacements, as forest clearings, little busy roads, trails and waterways, and inspected every 15 minutes, following criteria of Reis (1984).

After the capture, the measure of the forearm and the weight were taken and then the species identification was made. Two individuals from each species were deceased with intraperitoneal dose of sodium tiopenthal (Ortêncio Filho et al., 2005), and fixed in formaldehyde 10\% during 48 hours and, afterwards preserved in alcohol $70 \%$. The specimens were identified using stereoscopic microscope, according to Vizotto and Taddei (1973), Jones and Carter (1976) and Gregorin and Taddei (2002), confirmed by the Professor Dr. Adriano Lucio Peracchi (Universidade Federal Rural do Rio de Janeiro) and settled in the Laboratório de Zoologia from the Universidade Paranaense, Campus Cianorte.

All the captured bats were labeled with identification aluminum rings (Etiquetal-models 3.5 and 4.0), in their left forearm, allowing the verification of possible recaptures.

In order to analyze the pattern of time and seasonal activity of the bats, samplings were performed during one night per month, including the entire night period, from January to December, 2006, beginning from the moment when the light intensity was lower than 5 Lux, and ending when the same reached value higher than the previously cited, determined using the digital Minipa luximeter (MLM-1010). Thus, between April and August, the number of sampling hours was 12 hours and in the rest of the months, the sampling time was 11 hours, except in January, when the time was ten hours. The four seasons of the year were defined as: summer - January to March; autumn - April to June; winter - July to September and spring - October to December.

The studies were conducted to compare the pattern of time and seasonal activity of the most frequent frugivorous species. These species were divided into two categories: larger species (forearm between 59.4 and $75.0 \mathrm{~mm}$ ) and smaller species (forearm between 38.0 and $50.0 \mathrm{~mm}$ ), as it is the case of Artibeus planirostris (Spix, 1823), Artibeus lituratus (Olfers, 1818) and Artibeus fimbriatus Gray, 1838 and Sturnira lilium (E. Geoffroy, 1810), Carollia perspicillata (Linnaeus, 1758) and Platyrrhinus lineatus (E. Geoffroy, 1810), respectively (Ortêncio Filho and Reis, 2008).

The air temperature was measured at the beginning and at the end of the samplings, using psicrometer, and the precipitation data were provided by the Instituto 
Tecnológico SIMEPAR. The air temperature ranged from $10.0^{\circ} \mathrm{C}$ (August) to $31.3^{\circ} \mathrm{C}$ (December) with annual mean of $21.5^{\circ} \mathrm{C}$. The driest months were from April to June, with the lowest precipitation in May $(16.2 \mathrm{~mm})$, and the highest ones were verified from January to March and a peak during December $(259.0 \mathrm{~mm})$. The greatest precipitation levels coincided to the warmest months.

To statistically model the data, GLMs - generalized linear models were used (McCullagh and Nelder, 1989). The Poisson distribution (likelihood function) was assumed. The linkage function, which connects the expected value for the data to the linear predictors, was a log function. This function assures that all adjusted values are positive.

The Poisson function is described by the following equation:

$\mathrm{f}(\mathrm{k} \mid \lambda)=\frac{\lambda^{\mathrm{k}} \mathrm{e}^{-\lambda}}{\mathrm{k} !}$

where: $e$ is the Napierian logarithm basis ( $\mathrm{e}=2.71828 \ldots$ ); $\lambda$ - is the parameter of the function; $\mathrm{k}-$ is the number of the occurrences of one event, whose probability is calculated by the function; and $\mathrm{k}$ ! - is the factorial of $\mathrm{k}$

Both the expected value for the Poisson distribution and its variance are given by the parameter $\lambda$. The expected value was modeled in several ways for each species, including combinations of independent variables, 'hour' and 'season'. The variable 'hour' was modeled in two ways, as a discrete and as a continuous variable. When included as a discrete variable, $m-1$ parameters are estimated by the model, where $m$ is the number of levels for the variable. When modeled as a continuous variable, the time was included in the model in two ways: with values from one to 12 indicating the first until the twelfth hour of observations, or as a polynomial. The polynomials were orthogonal decompositions of the time in two or three new variables, but present the desirable performance without the occurrence of correlation among them (Chambers and Hastie, 1992). The model that best explained the activity tendency was chosen using the Akaike's Information Criterion for small samples (AICc) for the adjusted generalized linear models. The model with the lowest AICc represented the most parsimonious explanation of the data.

\section{Results}

During the sampling period, 512 bats captures were recorded. Artibeus planirostris was represented by 137 individuals (26.8\%), A. lituratus by 120 (23.4\%) and $A$. fimbriatus, by 32 bats (6.3\%), while Carollia perspicillata, Platyrrhinus lineatus and Sturnira lilium were the smaller species among the most frequent ones with 120 (23.4\%), $61(11.9 \%)$ and $42(8.2 \%)$ individuals.

In general, the captured bats in the Porto Rico region presented activity peaks in the fourth (total number of captures, $n=66$ ) and tenth hours $(n=53)$. Peaks of capture for larger frugivorous occurred during the fifth $(n=30)$ and tenth $(\mathrm{n}=35)$ hours, whereas for the smaller ones, the peaks were observed in the second $(n=29)$ and fourth ( $\mathrm{n}=37$ ) hours.

Artibeus planirostris did not present a clear time pattern (Table 1), with significant differences among some hours and higher activity during the fourth $(\mathrm{n}=16)$, eighth $(\mathrm{n}=17)$ and tenth $(\mathrm{n}=21)$ hours. Artibeus lituratus, species with occurrence during the entire night period, had a great number of captures in the sixth $(n=12)$, seventh $(n=15)$ and eleventh $(n=18)$ hours, with significant tendency of increase in the activity over the night only during the spring and autumn. Artibeus fimbriatus presented a significant increase in its activity over the night (Table 1) and the hours with the highest number of captures were the fifth and ninth, both with five individuals, and the sixth and the eleventh, each one, with four individuals (Figure 2).

Regarding the smaller species, $P$. lineatus was captured during all sampling hours, with the highest number of occurrences in the third $(n=7)$, sixth $(n=6)$, seventh $(n=6)$ and ninth $(n=8)$ hours, however without significant differences (Table 1). For C. perspicillata the influence of time on this activity was found, with a significant pattern of decrease in

Table 1. Models that best explain the temporal variation of bats species in fragments of a stational semidecidual forest from the Upper Paraná River, Southern Brazil. AICc is the value of adjusted Akaike's information criterion and $\Delta$ AICc is the difference between the model's AICc and the AICc for the best fitting model. The "+" represents models that only include main effects and "*"represents models that include the main effects as well as its interactions

\begin{tabular}{llccc}
\hline \multicolumn{1}{c}{ Species } & \multicolumn{1}{c}{ Model } & Number of parameters & AICc & $\Delta$ AICc \\
\hline Carollia perspicillata & season + hour & 5 & 625,0 & 0,0 \\
Artibeus lituratus & season + hour & 5 & 632,4 & 0,7 \\
& season * hour & 8 & 631,6 & 0,0 \\
Artibeus planirostris & season * factor(hour) & 46 & 741,2 & 0,0 \\
Artibeus fimbriatus & season + hour & 5 & 249,1 & 0,0 \\
& season + polynomial (hour, 2) & 6 & 249,8 & 0,8 \\
& season + polynomial (hour, 3) & 7 & 249,5 & 0,5 \\
Platyrrhinus lineatus & season & 4 & 365,8 & 0,0 \\
Sturnira lilium & season + hour & 5 & 313,9 & 1,5 \\
& season * hour & 8 & 312,5 & 0,0 \\
\hline
\end{tabular}


the activity over the time (Table 1), and greater number of individuals during the first four hours and capture peak in the first $(n=16)$, second $(n=17)$ and fourth $(n=23)$ and a new increase in the tenth hour, followed by subsequent reduction. Similar situation was verified for $S$. lilium that presented a significant decrease in activity (Table 1), at least during the summer and winter, with catches for the same hours with five, eight and ten individuals and a new peak in the eleventh hour (Figure 3).

In relation to the seasonal pattern, the models for all species included the factor season (Table 1) and, in general, the highest activity of bats was registered during the summer $(n=198)$ and autumn $(n=133)$. It was observed the predominance of larger frugivorous in the

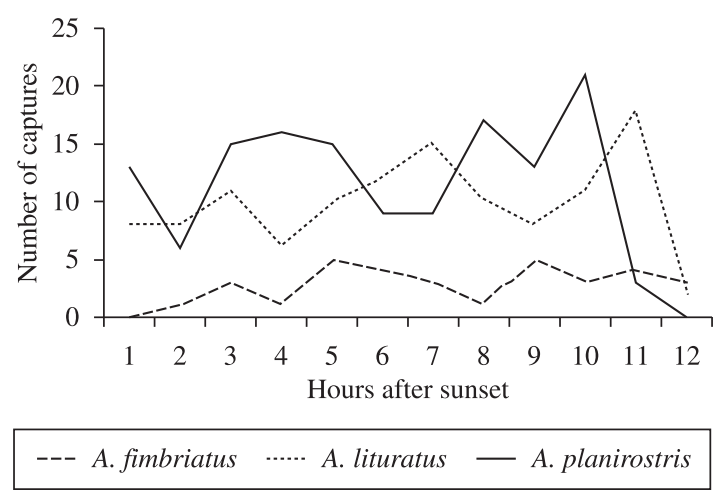

Figure 2. Time activity of Artibeus planirostris, A. lituratus and A. fimbriatus, larger frugivorous species which were most frequently sampled, based on captures using mist nets in fragments of stational semidecidual forest from the Upper Paraná River, Brazil, from January to December, 2006 (the twelfth sampling hour was performed from April to August due to longer nights).

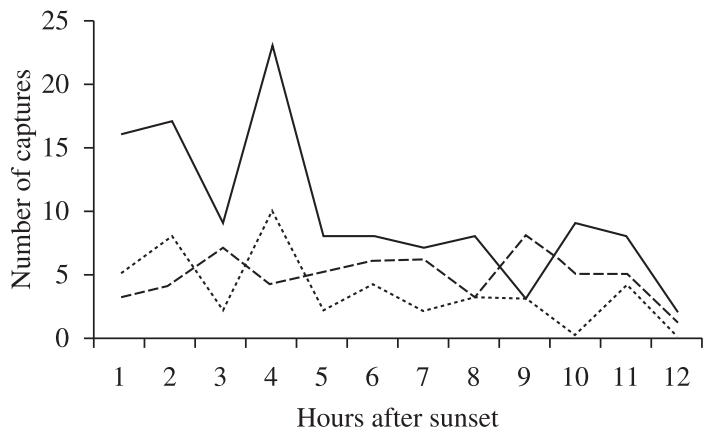

--- P. lineatus …-. S. lilium - C.perspicillata

Figure 3. Time activity of Carollia perspicillata, Sturnira lilium and Platyrrhinus lineatus, smaller frugivorous species which were most frequently sampled, based on captures using mist nets in fragments of stational semidecidual forest from the Upper Paraná River, Brazil, from January to December, 2006 (the twelfth sampling hour was performed from April to August due to longer nights). summer $(n=90)$ and spring $(n=75)$, similar situation for the smaller ones, more frequent in the summer $(n=82)$ and autumn $(\mathrm{n}=73)$.

Analyzing the seasonal pattern of activity (Figure 4), A. planirostris presented more occurrences during the summer $(\mathrm{n}=44)$ and winter $(\mathrm{n}=40)$, nevertheless, without a remarkable pattern over the night, in view of the occurrence of significant differences for the first hours and not significant for the middle of the night. Artibeus lituratus was significantly represented by specimens in the spring $(\mathrm{n}=45)$ and summer $(\mathrm{n}=40)$. Otherwise, $A$. fimbriatus was significantly recorded in the autumn $(\mathrm{n}=15)$ and winter $(\mathrm{n}=11)$.

For the smaller frugivorous, the highest values of occurrence were verified in the summer and autumn (Figure 5). Platyrrhinus lineatus presented number of individuals of 23 and 17, C. perspicillata, 43 individuals

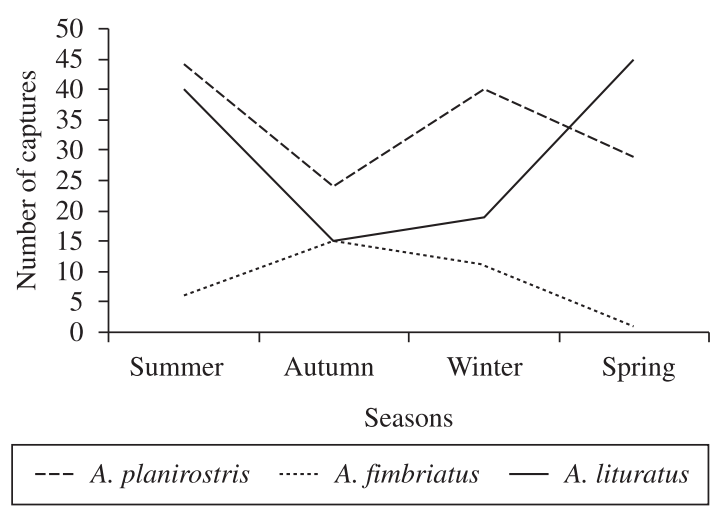

Figure 4. Seasonal activity of Artibeus planirostris, A. lituratus and $A$. fimbriatus, larger frugivorous species which were most frequently sampled, based on captures using mist nets in fragments of stational semidecidual forest from the Upper Paraná River, Brazil, from January to December, 2006.

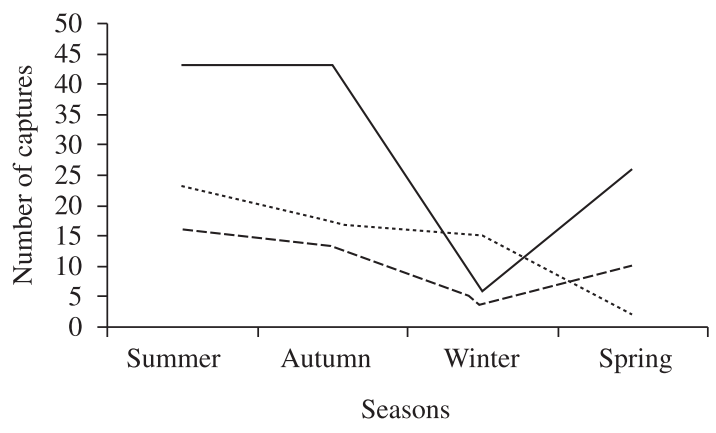

--- S. lilium …. P. lineatus - C. perspicillata

Figure 5. Seasonal activity of Carollia perspicillata, Sturnira lilium and Platyrrhinus lineatus, smaller frugivorous species which were most frequently sampled, based on captures using mist nets in fragments of stational semidecidual forest from the Upper Paraná River, Brazil, from January to December, 2006. 
in both seasons and S. lilium, 16 and 13, respectively. The spring was, significantly, the season with the lowest occurrence for $P$. lineatus $(\mathrm{n}=1)$ and the winter, for $C$. perspicillata $(\mathrm{n}=6)$ and S. lilium $(\mathrm{n}=4)$.

\section{Discussion}

The region of Porto Rico County encompasses areas with advanced stage of degradation, which, according to Reis et al. (2000), contribute for the disappearance of species sensible to anthropogenic impacts and favor the establishment of generalist ones.

Among the frugivorous bats, it was not verified the occurrence of well defined catch peaks, because the samplings were performed throughout the nocturnal period. Such result may indicate the coexistence among these species similar in diversified diet or by the sufficient amount of certain common items, avoiding the exhaustion in a same night (Muller and Reis, 1992). Bernard (2002) observed, in the Amazon Forest, low number of individuals of Artibeus genus after the nightfall and greater activity near dawn, whereas Marinho Filho and Sazima (1989) registered $A$. lituratus and A. planirostris during the entire night, however, with a peak between the third and fifth hours.

In other studies focusing the first middle of the nocturnal period, it was observed for A. lituratus, in a dense rain forest of lowlands in the Paraná State, higher catches frequency in the first and fifth hours (Fogaça, 2003). In other region with the same vegetation, two activity peaks were recorded for the species, one of them between the first and second hours after the nightfall and the other at forth hour (Oprea et al., 2007). In areas of stational semidecidual forest, capture peaks for this species were registered at forth hour after the nightfall (Marinho Filho and Sazima, 1989), between the second and third hours for A. lituratus and A. fimbriatus (Aguiar and Marinho Filho, 2004), and during the first and forth hours for the same two species, with a subtle increase in the third hour for A. fimbriatus (Ortêncio Filho and Reis, 2008).

The species from the Artibeus genus present generalist feeding habits, compounded by fruits of several species, with preference to Cecropiaceae and Moraceae, besides flowers, leaves and insects, which, combined to the large size, give them great adaptive success (Zortéa, 2007) and the ability to forage during different times of the night, they are also favored in anthropogenic impacted environments (Estrada and Coates Estrada, 2002). According to the same authors, other important factor would be that these animals can use several vegetation stratums.

Regarding the smaller species, activity during the entire night was observed, with peaks in the first and forth hours. This situation is probably related to a greater search for food in the first hours of the night. These animals spend the entire clear phase of the day in diurnal shelters, not feeding during this period, being under situations of energetic stress, which is associated to their smaller size. They may also compete with larger bats that use the same food resources.
Platyrrhinus lineatus activity was constant during the night, probably due to the resource partitioning, since this species feed mainly on fruits composed preferentially by those from the families Moraceae e Cecropiaceae (Willig and Hollander, 1987), and insects, as Artibeus.

Carollia perspicillata and S. lilium had highest activity during the first four hours, with a peak in this last one. Pedro and Taddei (1997), in a Cerrado area, found no difference in the time activity for these species.

In other researches in areas of stational semidecidual forest, Marinho Filho and Sazima (1989) registered $C$. perspicillata throughout the nocturnal period, with the highest number of catches at the second hour after the nightfall, whereas $S$. lilium presented the highest activity between the fourth and fifth hours; Muller and Reis (1992) did not observe difference in the time activity for these species whereas Aguiar and Marinho Filho (2004) verified higher number of catches at the second hour, and Ortêncio Filho and Reis (2008), at the fourth hour after the nightfall, probably due to questions related to the species biology, or to differences in relation to feeding preference (Pedro, 1992).

Because $P$. lineatus, $C$. perspicillata and S. lilium seek after different food resources, i.e., fruits of Moraceae and Cecropiaceae for the first species and Piperaceae and Solanaceae for the others, respectively (Nowak, 1994; Marinho Filho and Sazima, 1989; Muller and Reis, 1992; Zanon and Reis, 2007), the foraging time may be similar, because there is no competition. Nevertheless, Aguiar and Marinho Filho (2004) observed that, in a fragment from Atlantic Forest, C. perspicillata was more active when $S$. lilium was less frequent.

Other explanation for the occurrence of these animals during the entire night would be the small size and frugivorous habit, creating a situation of constant energetic stress (Thies et al., 2006), since these species present restrict ability to store fat (McNab, 1976).

In accordance to Brown (1968) and Laval (1970), the bats from the Neotropical region present higher activity during the first hours after the nightfall, probably, due to the fruits availability that are not replaced in the same night and, hence, the animals foraging earlier have more chance to find food (Heithaus et al., 1975). The time and the hour of activity are also influenced by the shelter proximity in relation to food sources, as well as by the environmental conditions, as temperature and humidity (Fenton and Kunz, 1977).

In relation to the bats periodicity, according to the year seasons, the warmer and wetter periods are commonly characterized, in tropical regions, by the abundance of frugivorous species (Heithaus et al., 1975), due to resource availability (Fleming, 1986), as observed in this study. Thehighest number of individuals occurred during the summer, which indicates a variation in the supply of food resources among the seasons, interfering in activity patterns of the species in the area. Additionally, in agreement with Aguirre et al. (2003), who studied forest environments, bats with more dependence of resources that varies seasonally, 
as frugivores, tend to have greater variation in activity over the year, compared to species with more constant diets, as insectivores.

In general, the larger frugivorous species were more active in the summer and spring. Artibeus planirostris and $A$. lituratus presented higher activity in these seasons, while A. fimbriatus was more frequent in the autumn. In regions of stational semidecidual forest, Aguiar and Marinho Filho (2004) recorded higher occurrence of this genus at the end of dry season and over the rainy months, and Marinho Filho and Sazima (1989) verified activity peak of A. lituratus during the dry season.

Galetti and Morellato (1994) emphasized that some Artibeus species generally consume fig tree fruits but common in the canopy. However, fig species do not fructify seasonally (Carauta and Diaz, 2002), therefore, the highest frequency of these animals during the warmer periods suggests a stronger relationship of them to resources with seasonal variation.

In the colder months, bats from the Artibeus genus are less frequent, probably due to the absence of Cecropiaceae fruits, one of its main food resources together with the fruits of Ficus, causing their displacement to other areas to search for this food (Passos et al., 2003). On the other hand, Fogaça (2003), in the rain forest of lowlands, observed an activity peak in the autumn, and lower ones during the winter, spring and summer.

Overall, the capture peaks occurred in the summer and the lowest number of occurrences in the winter. Although the number of records for $P$. lineatus, $C$. perspicillata and $S$. lilium had decreased in the colder seasons, the occurrence of individuals from these species was registered throughout the year, similar result found by Pedro and Taddei (1997, 2002), which observed the absence of temporal segregation based on annual activity for C. perspicillata and S. lilium. The variation in the number of catches according to the seasons may be associated to the dynamics of forest fragments and to the bats displacement (Aguiar and Marinho Filho, 2004). Furthermore, the phyllostomids maintain the body temperature even when the environmental temperatures are low, which would cause a greater energy loss during the flight (Thies et al., 2006), which is proven by the decrease in the captures in the colder months for C. perspicillata and S. lilium.

Agosta et al. (2005) highlighted the temperature influence on the exit of bats from the shelter that support the results obtained in the present study, considering the decrease in the number of animals in the nets associated to the temperature drop. The values of capture for $P$. lineatus, higher in the summer, and lower in the spring and winter, may be related to the fruits availability used in its alimentation. Pedro and Taddei (2002) pointed that, in periods of absence of these components in the diet, the species search other regions where these resources are available. The same authors, in a Cerrado area, reported that $S$. lilium and $P$. lineatus were more active during the wettest and warmest month due to the fruits availability.
The hypothesis that there is variation in time and seasonal pattern of activity of phyllostomid frugivorous bats in remnants of stational semidecidual forest from the Upper Paraná River, Brazil, was corroborated since the obtained data suggest a similar pattern of time activity for larger frugivorous species, whereas the smaller ones focused their activity in the first hours of night. Furthermore, more animals were captured during summer, probably in function of food resource availability, as well as the lower loss of heat due to higher temperatures. These results evidence the high adaptive potential of studied species to time variation and environmental conditions.

Acknowledgements - We would like to thank Universidade Estadual de Maringá and Universidade Paranaense for the incentive and financial support; Aldair Tavares de Souza, Aline Farias Zanetti, Danieli Carvalho Vieira, Danieli Pinto, Émerson Jamber, Gisele Camilloti Paulino, Gustavo Barizon Maranho, Loseni Budny, Marcelo Aparecido Marques, Regiane Anderson, Rosiane Rufino Fernandes, Sandra Mara Milani Nishimura and Sílvia Regina Ferreira for the fundamental support, participation and help in the captures and the friends Priscilla Carvalho, Marcos Magalhães and Carlos Alberto de Oliveira Magalhães Júnior for the suggestions in this manuscript.

\section{References}

AGOSTA, SJ., MORTON, D., MARSH, BD. and KUHN, KM., 2005. Nightly, seasonal, and yearly patterns of bat activity at night roosts in the Central Appalachians. Journal of Mammalogy, vol. 6, no. 86, p. 1210-1219.

AGOSTINHO, AA. and ZALEWSKI, MA., 1996. A planície alagável do alto rio Paraná: importância e preservação. Maringá: EDUEM, $100 \mathrm{p}$.

AGUIAR, LMS. and MARINHO FILHO, J., 2004. Activity patterns of nine phyllostomid bat species in a fragment of the Atlantic Forest in Southeastern Brazil. Revista Brasileira de Zoologia, vol. 2, no. 21, p. 385-390.

AGUIRRE, RF., LENZ, L., DAMME, R. van. and MATTHYSEN, E., 2003. Consistence and variation in the bats assemblages inhabiting two forest islands within a neotropical savanna in Bolivia. Journal of Tropical Ecology, no. 19, p. 367-374.

BERNARD, E., 2002. Diet, activity and reproduction of bats species (Mammalia, Chiroptera) in Central Amazônia, Brazil. Revista Brasileira de Zoologia, vol. 1, no. 19, p. 173-188.

BROWN, JH., 1968. Activity patterns of some neotropical bats. Journal of Mammalogy, vol. 4, no. 49, p. 754-757.

CAMPOS, JB. and SOUZA, MC., 1997. Vegetação. In VAZZOLER, AEA., AGOSTINHO, AA. \& HAHN, NS. (Eds.). A planície de inundação do alto rio Paraná: aspectos físicos, biológicos e socioeconômicos. Maringá: EDUEM, p. 331-342.

CARAUTA, JPP. and DIAZ, BE., 2002. Figueiras no Brasil. Rio de Janeiro: UFRJ, $212 \mathrm{p}$.

CHAMBERS, JM. and HASTIE, TJ., 1992. Statistical models in $S$. California: Wadsworth \& Books, 608 p.

CORREA, GT., 1998. O uso do solo no arquipélago Mutum - Porto Rico - alto rio Paraná, PR/MS. Maringá: Universidade Estadual de Maringá, 27 p. [Dissertação de Mestrado]. 
ESTRADA, A. and COATES ESTRADA, R., 2002. Bats in continuous forest, forest fragments and in an agricultural mosaic habitat-island at Los Tuxtlas, Mexico. Biological Conservation, vol. 2, no. 103, p. 237-245.

FENTON, MB. and KUNZ, TH., 1977. Movements and behavior. Lubbock: Museum Texas Tech University, no. 13, p. 351-364. Special Publications.

FENTON, MB., ACHARYA, L., AUDET, D., HICKEY, MBC., MERRIMAN, C., OBRIST, MK. and SYME, DM., 1992. Phyllostomid bats (Chiroptera: Phyllostomidae) as indicators of habitat disruption in the Neotropics. Biotropica, no. 24, p. $440-446$.

FLEMING, TH., 1986. Opportunism vs. specialization: the evlution of feeding strategies in frugivorous bats. In ESTRADA, A. and FLEMING, TH. (Eds.). Frugivores and seed dispersal. Dordrecht: W. Junk Publishers, p. 105-118.

FOGAÇA, FNO., 2003. Chiroptera (Mammalia) do Parque Florestal Rio da Onça (Matinhos, PR). Curitiba: Universidade Federal do Paraná, 2003. 56p. [Dissertação de Mestrado].

GALETTI, M. and MORELLATO, LPC., 1994. Diet of the large fig-eating bat Artibeus lituratus in a forest fragment in Brazil. Mammalia, no. 58, p. 661-665

GARDNER, AL., 1977. Feeding habits. In BAKER, RJ., JONES $\mathrm{Jr}$, JK. and CARTER, DC. (Eds.). Biology of the bats of the new world family Phyllostomatidae. Lubbock: Museum Texas Tech University, vol. 13, 364 p. Special Publications.

GOITI, U., AIHARTZA, JR., ALMENAR, D., SALSAMENDI, E. and GARIN, I., 2006. Seasonal foraging by Rhinolophus euryale (Rhinolophidae) in an Atlantic rural landscape in northern Iberian Peninsula. Acta Chiropterologica, vol. 1, no. 8, p. 141-155.

GOODWIN, GG. and GREENHALL, AM., 1961. A review of the bats of Trinidad and Tobago. Bulletim of the American Museum of Natural History, vol. 122, no. 3, p. 187-302.

GREENHALL, AM. and PARADISO, JL., 1968. Bats and bat banding. Bureau of Sport Fisheries and Wildlife Resource Publication, no.72, p. 1-47.

GREGORIN, R. and TADDEI, VA., 2002. Chave artificial para identificação de molossídeos brasileiros (Mammalia, Chiroptera). Mastozoologia Neotropical, vol. 1, no. 9, p. 13-32.

HEITHAUS, ER., FLEMING, TH. and OPLER, PA., 1975. Foraging patterns and resource utilization in seven species of bats in a seasonal tropical forest. Ecology, vol. 4, no. 56, p. 841-854.

Instituto Agronômico de Paraná - IAPAR, 1994. Cartas climáticas do estado do Paraná. Londrina, 45 p.

JONES, JK. and CARTER, DC., 1976. Annotated checklist, with keys to subfamilies and genera. In BABER, RJ., JONES Jr., JK. and CARTER, DC. (Eds.). Biology of bats of the new world family Phyllostomidae, part I. Lubbock: Museum Texas Tech. University, p. 7-38. Special Publications.

LAVAL, RK., 1970. Banding returns and activity periods of some Costa rican bats. Southwestern Naturalist, no. 15, p. 1-10.

MARINHO FILHO, JS. and SAZIMA, I., 1989. Activity patterns of six phyllostomid bat species in southeastern Brazil. Brazilian Journal of Biology, vol. 3, no. 49, p. 777-782.

MCCULLAGH, P. and NELDER, JA., 1989. Generalized linear models. London: Chapman and Hall, $511 \mathrm{p}$.
MCNAB, BK., 1976. Seasonal fat reserves of bats in two tropical environments. Ecology, no. 57, p. 332-338.

MEDELLÍN, RA., EQUIHUA, M. and ALMIN, MA., 2000. Bat diversity and abundance as indicators of disturbance in neotropical rainforests. Conservation Biology, vol. 6, no. 14, p. 1666-1675.

MORRISON, DW., 1978. Lunar phobia in a neotropical fruit bat Artibeus jamaicensis. Animal Behavior, vol. 3, no. 26, p. 852-855.

MULLER, MF. and REIS, NR., 1992. Partição de recursos alimentares entre quatro espécies de morcegos frugívoros (Chiroptera, Phyllostomidae). Revista Brasileira de Zoologia, vol. 9, no. 3-4, p. 345-355.

NOWAK, RM., 1994. Walker's Bats of the World. Baltimore: The Johns Hopkins University Press, 287 p.

ODUM, E. and BARRETT, GW., 2007. Ecologia da Paisagem. In ODUM, E. and BARRETT, GW. Fundamentos de ecologia. São Paulo: Thomson Learning, p. 374-411.

OPREA, M., BRITO, D., VIEIRA, TB., MENDES, P., LOPES, SM., FONSECA, RM., COUTINHO, RZ. and DITCHIFIELD, AD., 2007. A note on the diet and foraging behavior of Artibeus lituratus (Chiroptera, Phyllostomidae) in an urban park in southeastern Brazil. Biota Neotropica, vol. 7, no. 2. Available from: <http:// www.biotaneotropica.org.br/v7n2/pt/abstract?article+bn014070 22007ISSN 1676-0603>. Access in: 24 Oct. 2007.

ORTÊNCIO FILHO, H. and REIS, NR., 2008. Padrão de atividade horária e sazonal de morcegos (Chiroptera; Phyllostomidae) do Parque Municipal do Cinturão Verde de Cianorte, Paraná, Brasil. In REIS, NR., PERACCHI, AL. and SANTOS, GASD. (Eds.). Ecologia de morcegos. Londrina: Nelio Roberto dos Reis, p. 41-49.

ORTÊNCIO FILHO, H., REIS, NR., PINTO, D., ANDERSON, R., TESTA, DA. and MARQUES, MA., 2005. Levantamento dos Morcegos (Chiroptera, Mammalia) do Parque Municipal do Cinturão Verde de Cianorte, Paraná, Brasil. Chiroptera Neotropical, vol. 11 , no. 1-2, p. 211-215

PASSOS, FC., SILVA, WR., PEDRO, WA. and BONIN, MR., 2003. Frugivoria em morcegos (Mammalia, Chiroptera) no Parque Estadual Intervales, sudeste do Brasil. Revista Brasileira de Zoologia, vol. 3, no. 20, p. 511-517.

PEDRO, WA. and TADDEI, VA., 1997. Taxonomic assemblage of bats from Panga Reserve, southeastern Brazil: abundance patterns and trophic relation in the Phyllostomidae (Chiroptera). Boletim do Museu de Biologia Mello Leitão, vol. 6, p. 3-21.

-, 2002. Temporal distribution of five bat species (Chiroptera, Phyllostomidae) from Panga Reserve, south-eastern Brazil. Revista Brasileira de Zoologia, vol. 19, no. 3, p. 951-954.

PEDRO, WA., 1992. Estrutura de uma taxocenose de morcegos da Reserva do Panga (Uberlândia, $M G$ ), com ênfase nas relações tróficas em Phyllostomidae (Mammalia: Chiroptera). Campinas: Universidade Estadual de Campinas, 110 p. [Dissertação de Mestrado].

-, 1998. Diversidade de morcegos em hábitats florestais fragmentados do Brasil (Chiroptera, Mammalia). São Carlos: Universidade Federal de São Carlos, 128 p. [Tese de Doutorado].

PETERS, SL., MALCOLM, JR. and ZIMMERMAN, ABL., 2006. Effects of selective logging on bat communities in the southeastern Amazon. Conservation Biology, vol. 5, no. 20, p.1410-1421. 
PIANKA, ER., 1969. Sympatry of desert lizards (Ctenotus) in western of Australia. Ecology, no. 50, p. 1012-1030.

PIRES, AS., FERNANDEZ, FAS. and BARROS, CS., 2006. Vivendo em um mundo em pedaços: efeitos da fragmentação florestal sobre comunidades e populações animais. In ROCHA, CFD., BERGALLO, HG., SLUYS, MV. and ALVES, MAS. (Eds.). Biologia da Conservação. São Carlos: RiMa, p. 231-260.

REIS, NR., 1984. Estrutura de comunidade de morcegos da região de Manaus, Amazonas. Brazilian Journal of Biology, vol. 3 , no. 44 , p. $247-254$.

REIS, NR., PERACCHI, AL., LIMA, IP. and PEDRO, WA., 2006. Riqueza de espécies de morcegos (Mammalia, Chiroptera) em dois diferentes habitats, na região centro leste, Telêmaco Borba (PR), sul do Brasil. Revista Brasileira de Zoologia, vol. 3, no. 23, p. 813-816.

REIS, NR., PERACCHI, AL., SEKIAMA, ML. and LIMA, IP., 2000. Diversidade de morcegos (Chiroptera: Mammalia) em fragmentos florestais no estado do Paraná, Brasil. Revista Brasileira de Zoologia, vol. 3, no.17, p. 697-704.

REIS, NR., SHIBATTA, OA., PERACCHI, AL., PEDRO, WA. and LIMA, IP., 2007. Sobre os morcegos brasileiros. In REIS, NR., PERACCHI, AL., PEDRO, WA. and LIMA, IP. (Eds). Morcegos do Brasil. Londrina: Nelio Roberto dos Reis, p.17-25.

SCHOENER, TW., 1974. Resource partitioning in ecological communities. Science, no. 185, p. 27-39.

SIPINSKI, EAB. and REIS, NR., 1995. Dados ecológicos dos quirópteros da Reserva Volta Velha, Itapoá, Santa Catarina, Brasil. Revista Brasileira de Zoologia, vol. 3, no. 12, p. 519-528.

SOUZA, MC. and KITA, KK., 2002. Formações vegetais ripárias da planície alagável do alto rio Paraná, estados do Paraná e Mato Grosso do Sul, Brasil. In: Universidade Estadual de Maringá - UEM. Nupélia/PELD. A planície de inundação do alto rio Paraná. Maringá: Nupélia, 2002. p. 197-201. Site 6. Available from: <http://www.peld. uem.br/Relat2002/index02.htm>. Access in: 14 June 2005.

SOUZA, MC. and MONTEIRO, R., 2005. Levantamento florístico em remanescente de floresta ripária no alto rio Paraná: Mata do
Araldo, Porto Rico, Paraná, Brasil. Acta Scientiarum, vol. 4, no. 27 , p. $405-414$.

SOUZA, MC., 2004. Vegetação ripária. In Universidade Estadual de Maringá. Nupélia/PELD. A planície de inundação do alto rio Paraná: Site 6 PELD/CNPq - Relatório anual 2004. Maringá. Available from: <http://www.peld.uem.br/Relat2004/pdf/vegetaçao_ riparia2004.pdf >. Access in: 04 Nov. 2007.

SOUZA, MC., KITA, KK., SLUSARSKI, SR., TOMAZINI, V., PEREIRA, GF., FONTANA, AC. and ZAMPAR, R., 2005. Vegetação ripária (Mata Ciliar). In Universidade Estadual de Maringá - UEM. Nupélia/PELD. A planície de inundação do alto rio Paraná. Maringá: Nupélia, 2005. p. 190-205. Site 6 PELD/ CNPq - Relatório anual 2005. Available from: $<$ http://www.peld. uem.br/Relat2005/pdf/19_VegetacaoRiparia2005a.pdf>. Access in: 04 Nov. 2007.

STRAUBE, FC. and BIANCONI, GV., 2002. Sobre a grandeza e a unidade utilizada para estimar esforço de captura com utilização de redes-de-neblina. Chiroptera Neotropical, vol. 1-2, no. 8, p. $150-152$.

THIES, W., KALKO, EKV. and SCHNITZLER, HU., 2006. Influence of environment and resource availability on activity patterns of Carollia castanea (Phyllostomidae) in Panama. Journal of Mammalogy, vol. 2, no. 87, p. 331-338.

VAN DER PJIL, L., 1957. The dispersal of plants by bats (Chiropterochory). Acta Bothanic of Neerland, vol. 6, p. 291-315.

VIZOTTO, LD. and TADDEI, VA., 1973. Chave para determinação de quirópteros brasileiros. Boletim de Ciências, vol. 1, p. 1-72.

WILLIG, MR. and HOLLANDER, RR., 1987. Vampyrops lineatus. Mammalian species, no. 275, p. 1-4.

ZANON, CMV. and REIS, NR., 2007. Bats (Mammalia, Chiroptera) in the Ponta Grossa region, Campos Gerais, Paraná, Brazil. Revista Brasileira de Zoologia, vol. 2, no. 24, p. 327-332.

ZORTÉA, M., 2007. Subfamília Stenodermatinae. In REIS, NR., PERACCHI, AL., PEDRO, WA. and LIMA, IP. (Eds.). Morcegos do Brasil. Londrina: Nelio Roberto dos Reis, p. 107-128. 
